\title{
Assessment on the Economic and Environmental Benefits of Household Waste Management through Vermicomposting
}

\author{
Nisha Arya ${ }^{1}$, Dr. Shishir Kala ${ }^{2}$ \\ ${ }^{1} \mathrm{PhD}$ Scholar, Department of Family and Community Resource Management, \\ Faculty of Family and Community Science, MS University of Baroda, Vadodara Gujarat \\ ${ }^{2}$ Professor, Department of Family Resource Management, College of Community Science, \\ RPCAU Pusa, Samastipur, Bihar, 848125 India
}

\begin{abstract}
Household waste management is a crucial task owing to the increasing amount of pollution in the environment and the wide range of different components in this solid waste. Household waste is mostly comprised of biodegradable and highly putrescible kitchen waste. Through the activity of earthworms, such waste can be recycled with vermicomposting, and this bio-conversion of organic waste material transforms waste into nutrient-rich 'Vermicompost,' benefiting both the economy and the environment. With this context, the present study was undertaken to determine the impact of household waste management through vermicomposting on environment and to find out the economic benefits of household waste management through vermicomposting and to identify constraints perceived by households during the household waste management through vermicomposting. The present study was descriptive in nature. Purposive random sampling was used to scrutinize 60 households and the locale of study was RPCAU Pusa Campus. The data was gathered by using a well-structured interview schedule and the personal interview-cum-observation method. The results of the study revealed that more or less every household in the university's residential area generates approximately 1.12 $\mathrm{kg}$ of waste, of which $68.75 \%$ was biodegradable and $31.25 \%$ was non-biodegradable waste. Respondents agreed that vermicomposting eliminates the use of chemical fertilizers in their gardens and farms $(62 \%)$, disposing of waste in random areas has been reduced (55\%), it helps to create a greener and healthier environment than before (48\%) and stench from overfilled garbage bins and uncollected waste on roadside has been reduced (42\%). The present study revealed the cost benefit ratio was 1.44 showed that vermicomposting as a tool of HWM could be an attainable and feasible enterprise and hence can generate the revenue and employment. This study encourages both government and private organizations to use eco-friendly technology to reduce, recycle, and manage waste through vermicomposting in order to achieve a positive impact on the environment. Furthermore, the current study promotes youth and farmers to use low-cost HWM technology such as vermicomposting to earn significant benefits and increase farm income.
\end{abstract}

Keywords: Household waste, Waste Management, Vermicompost, Environment, Economic benefits,

\section{INTRODUCTION}

Solid waste management is a global issue that affects every person on the planet. And because over $90 \%$ of waste is dumped or burned openly, health and environment most vulnerable are disproportionately affected (Gutberlet \& Uddin, 2017). Open dumping of solid waste generates soil and water contamination as well as methane and other gas emissions, posing risks to human and environmental health (King et al., 2006). An update to a previous edition, the World Bank 2018 reported that rapid urbanization, population growth, and economic development will push global waste to increase by $70 \%$ over the next 30 years - to a staggering 3.40 billion tons of waste generated annually. Waste management infrastructure and services target the collection and transport of household waste, with the aim of maintaining and guaranteeing public health (Heynen et al. 2006; Gutberlet \& Uddin, 2017).

Household waste has evolved into a major municipal challenge, with increased waste generation and more complex material compositions, which frequently contain toxic and hazardous elements. Household waste generated in residents is an organic matter reserve that can be used to produce energy as well as focus on solving the waste disposal problems prudently. Household waste disposal remains an urgent hygiene and sanitation issue in India, as incautious management not only causes diseases and unpleasant odors, but also contributes significantly to global warming by releasing methane from decaying waste (IORA, 2014). This waste is produced by a variety of household activities, including elaborate cooking, packaging, pets, product use, and biomedical waste. This garbage primarily consists of solid waste materials from biodegradable waste, such as cooked and uncooked scraps, including eggshells and bones, flower and fruit waste, 


\section{DOI: 10.17148/IARJSET.2021.81212}

including juice peels and houseplant waste, as well as all types of green waste. Food or cooking waste feedstock contains a variety of beneficial microbial substrates such as proteins, lipids, carbohydrates, starch, amino carbohydrates, chitin, cellulose, lignin, crude fiber, and other compounds (Hanc and Pliva 2013).

Unmanaged waste is scattered in the area and finds its way to water bodies via a variety of routes. Once there, it contaminates the water and degrades the standard of water resources in nature. It also makes soil infertile, allowing farmers to use water sources for crop irrigation, lowering agricultural productivity. Improper garbage disposal techniques frequently block garbage chutes, resulting in stagnant water that starts to decay or decompose. When residual waste decomposes on landfills, it creates unsanitary conditions, releases foul odors that irritate the lungs, and has a negative impact on human respiratory systems. Land-based decomposition emits carbon dioxide and other harmful gases while trapping heat. Greenhouse gases are one of the major contributors to the world's severe weather changes. To address certain sanitation, environmental, and human health issues, there is a desire for an effective strategy to collect, treat, and properly dispose of household waste, referred to as household waste management, that has a versatile impact on human health and the environment.

Waste, in layman's terms, is defined as "things that are undesirable and not worthwhile." In reality, waste is nothing more than useful material in the wrong place (Desa et.al. 2012). Dr. Sunil Kumar (2019) stated in an interview, "When considering solutions, no matter how advanced the solution is, it will not be effective unless and until it is applied to the ground zero level." Modern science has proven that there isn't a single material on the planet that isn't valuable in some way, and this has changed the definition of waste. What exactly is waste? A potential resource that could help to promote sustainable development. Waste should now be viewed as a potential fertilizer source as well as a source of agricultural energy (State of Green, 2020).

In agriculture, vermicompost is quickly becoming a viable supplement to and replacement for artificial fertilisers. It is an important component in the development of sustainable agriculture and wasteland. It's a growth promoter that helps plants get the hormones they need to flourish. Farmers are eager to employ vermicompost since it improves the quality of agricultural products while also being less expensive. It's also popular in container gardening and home gardens. Furthermore, numerous government ministries, such as agriculture, forestry, and horticulture, purchase it in large quantities. Its popularity has expanded over the years. Das et.al. (2017) observed a farmer, Shri Bhikhari Mehta, ran a small scale of vermicomposting unit for his livelihood and became a popular manufacturer of quality products to know the efficiency of the wste management through vermicomposting technology. He determined that vermicomposting is an easy, informal and faster process of renovating organic matter into compost than other straight methods. The benefit-cost ratio $(1.87: 1)$ is deliberately higher and by adopting this bio-technology by farmers and other organisations can improved Indian economy which is the critical need of today. Consequently, this analysis showed that cost of vermicompost production and marketing was fair and the returns obtained were higher, suggesting a competitive scenario for the producers. He also recommended the NGO's, and government organizations increased their demands for vermicompost. Besides this, he encouraged nearby farmers to make this multifunctional fertilizer to use that in farmlands to have benefit to the farming community. According to Sharma et al. (2019), the waste management sector in India has the potential to deliver an additional $\$ 14$ billion in funding to the nation's economy with a high annual growth rate of $7 \%$ in the next years. As a result, all that is required is to turn the waste management problem into a profitable solution that provides work opportunities/employment for skilled, unskilled, and semi-skilled individuals while also contributing to a clean and sanitary environment.

Statement of the problem: The present study was undertaken to determine the impact of household waste management through vermicomposting on environment and to find out the economic benefits of household waste management through vermicomposting.

\section{Objective of the study:}

i.To determine the impact of household waste management through vermicomposting on environment ii.To find out the economic benefits of household waste management through vermicomposting

\section{METHODOLOGY:}

The present study is descriptive in nature and purposive random sampling have been done to select 60 respondents from the residential area of RPCAU Pusa University. A project was started to collect household waste from the University residents and use it for making vermicompost at vermicompost unit which has been proved as effective and eco-friendly way of managing household waste by University. Separation of biodegradable and non-biodegradable waste into two separate bins, i.e. green and yellow bins, at the source, two garbage pickers perform door-to-door rubbish collection service to houses from various University's residential areas. After collecting waste from residents of the University of Pusa's campus, garbage pickers transfer the material to the Vermicompost Unit near Poultry Farm Pusa for further sorting, 


\section{DOI: 10.17148/IARJSET.2021.81212}

composting, and recycling. Windrows are made for vermicomposting from biodegradable trash and cow dung, which are blended in equal parts for vermicomposting (50:50). The epigiec earthworm species, Esenia fetida (red wigglers), Eudrillus eugeniee (African night crawler), and Perionyx excavates (Indian blues or composting worms), are employed at $2 \mathrm{~kg}$ per ton of material in windrows at optimal temperature and moisture under shady and dry conditions. Under aerobic circumstances, worms stimulate and improve the biodegradability of organic matter in the heap. Regular monitoring is necessary to prevent overheating in the compost because in extreme hot or cold circumstances, earthworms (red wigglers) will slow down reproduction and feeding and may even die if temperatures go too high. After 60-70 days, vermicompost is ready for sale and use by farmers and other stakeholders, and the process is repeated. This vermicomposting technology not only aids in the improvement the environment of the university's campus but also helps in revenue generation.

The questionnaire was designed to obtain data from respondents through an interview schedule and observation method. The present study is divided into 4 sections. Section 1 contained demographic profile of the respondents includes, age, gender, occupation, family size, family type, family income and education status of families. Section 2 deals with the waste generation at RPCAU residential campus in terms of per capita and household (in $\mathrm{kg}$ ) per day by the respondents from the residential area of RPCAU Pusa University. Section 3 deals with the environmental benefits observed by respondents and enquire by the researcher as a result of household waste management through vermicompost production. The response structure was 'Strongly disagree', 'disagree', 'neutral', 'agree' and 'strongly disagree'. Section 4 contains a report on the potential revenue generation from vermicomposting technology includes the cost benefits ratio.

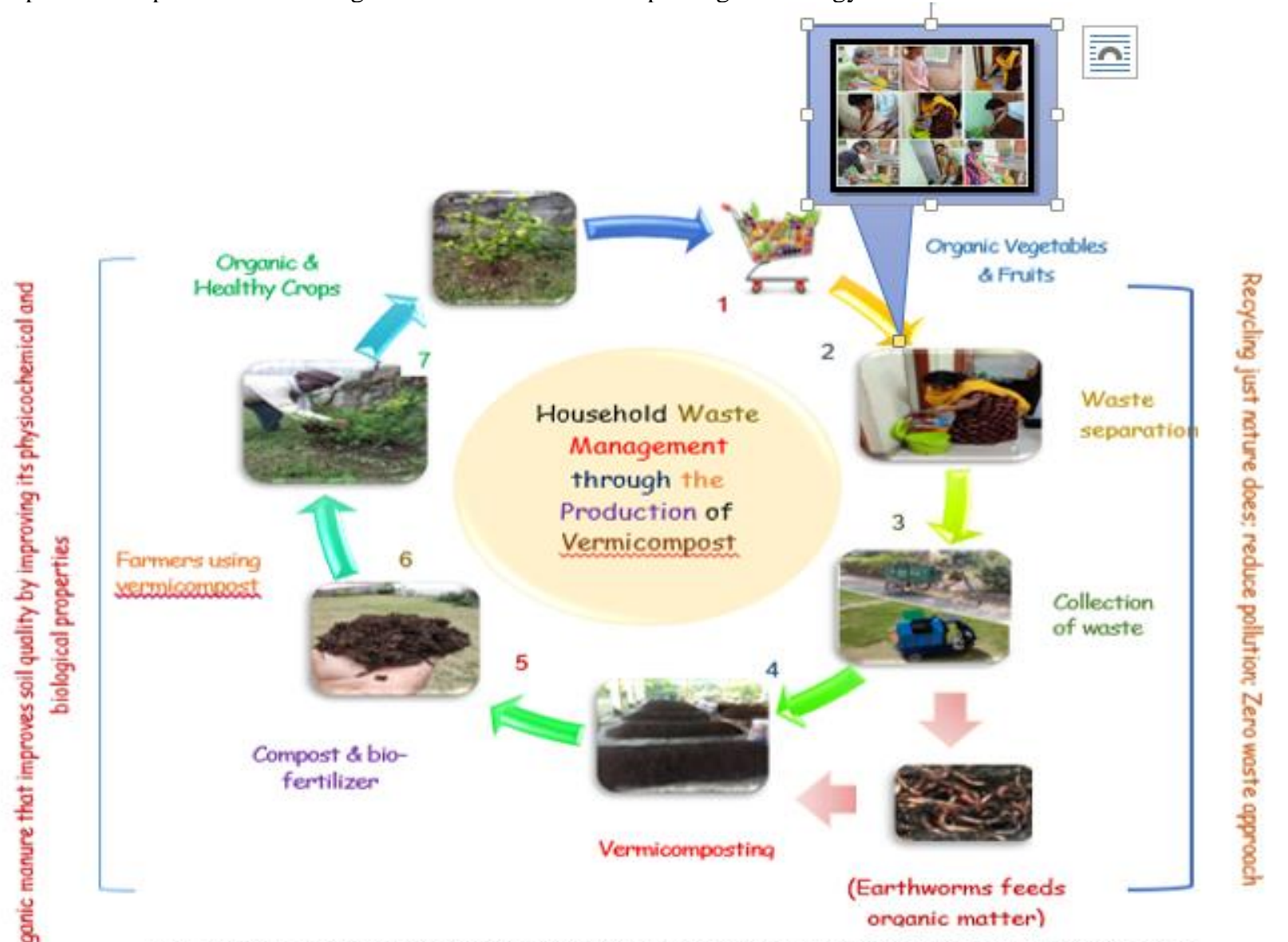

Fig 1. Cycle Diagram of Household Waste Management through the Production of Vermicompost

\section{FINDINGS OF THE STUDY:}

3.1 Demographic profile of respondents: This section includes pertinent data on the respondents. The age, gender, educational qualification, occupation, and income of the respondents are shown here.

Females made up more than four-fifth of the respondents $(82 \%)$. The administrative staff accounted for more than half $(55 \%)$ of the respondents. Around one-half of the respondents (50\%) had 3-4 members in their family. Furthermore, more than one-half of the respondents (52\%) earn more than Rs.50,000 per month and more than two-fifth (44\%) of the 
Vol. 8, Issue 12, December 2021

DOI: 10.17148/IARJSET.2021.81212

respondents were belonged to high income group. Moreover, on an average more than one-half (57\%) of the respondents are educated to a middle level.

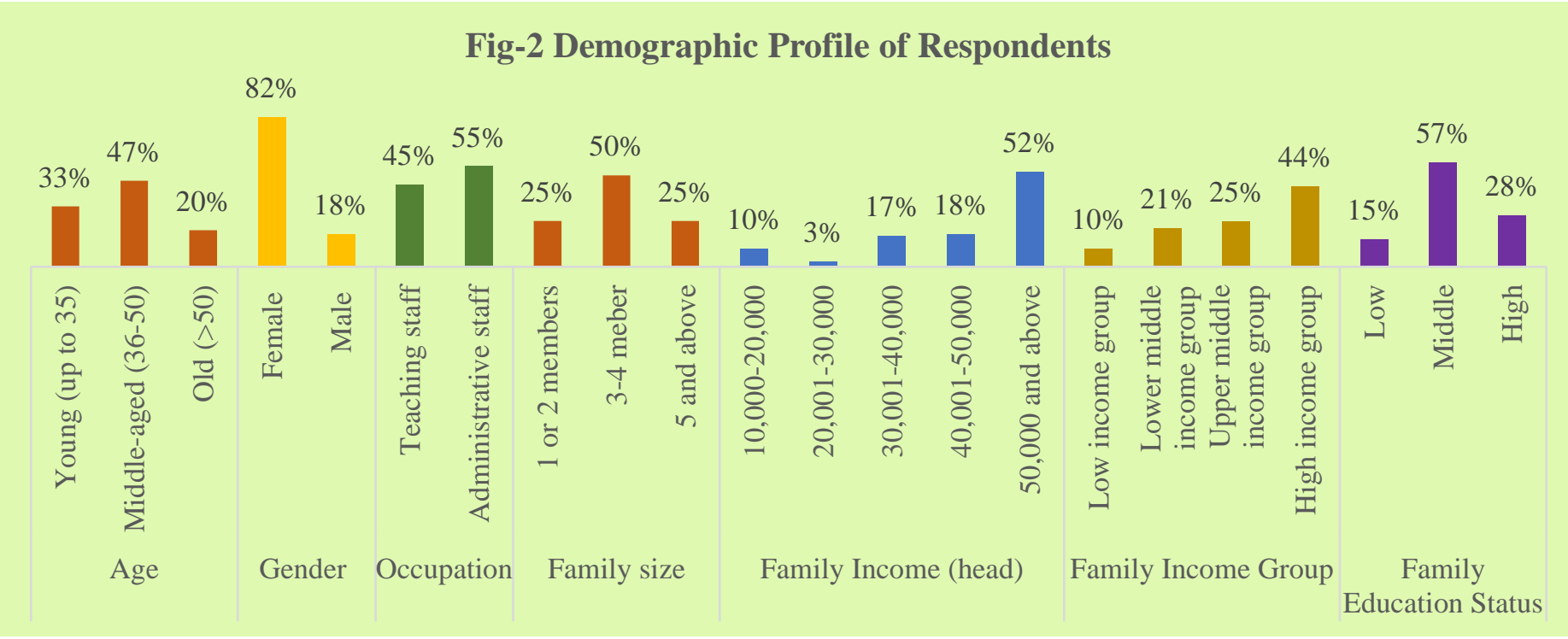

Figure 2 reveals that less than half of the respondents $(47 \%)$ were between the middle ages of 36 and 50.

Waste Generation at RPCAU residential campus: This section deals with the evaluation of waste generation by the respondents of RPCAU residential campus at individual level (kg/capita) and household level (kg/household) in a day.

Table:1 Waste Generation Per Capita Per Day

\begin{tabular}{|c|c|c|c|}
\hline Type of waste & $\begin{array}{l}\text { Total Waste } \\
\text { generation by the } 60 \\
\text { households/day }\end{array}$ & $\begin{array}{l}\text { Waste generation } \\
\text { at individual level } \\
(\mathrm{kg}) \text { / capita in a } \\
\text { day }\end{array}$ & $\begin{array}{l}\text { Waste generation } \\
\text { at household level } \\
\text { (kg/household) in } \\
\text { a day }\end{array}$ \\
\hline $\begin{array}{l}\text { Biodegradable waste generation per capita per } \\
\text { day }\end{array}$ & $45.81 \mathrm{~kg} /$ day & $0.21 \mathrm{~kg} /$ capita & $0.76 \mathrm{~kg}$ \\
\hline $\begin{array}{l}\text { Non-biodegradable waste generation per } \\
\text { capita per day }\end{array}$ & $21.52 \mathrm{~kg} /$ day & $0.10 \mathrm{~kg} /$ capita & $0.35 \mathrm{~kg}$ \\
\hline Total waste generation per day & $67.33 \mathrm{~kg} / \mathrm{day}$ & $0.31 \mathrm{~kg} / \mathrm{capita}$ & $1.12 \mathrm{~kg}$ \\
\hline
\end{tabular}

Above table 1 represents that the on an average at individual level $0.21 \mathrm{~kg} / \mathrm{capita}$ of biodegradable waste, $0.10 \mathrm{~kg} / \mathrm{capita}$ of non-biodegradable waste and total $0.31 \mathrm{~kg} /$ capita waste generated at individual level in a day. At household level 0.76 $\mathrm{kg}$ of biodegradable waste and $0.35 \mathrm{~kg}$ of non-biodegradable waste and total $1.12 \mathrm{~kg}$ of total waste generated in a day by the residence of RPCAU Pusa University.

3.3 Waste separation and waste management services used by respondents:

This section examines the respondents' waste separation practices and the use of waste management services provided through the project vermicomposting as a tool for household waste management. 
International Advanced Research Journal in Science, Engineering and Technology

Vol. 8, Issue 12, December 2021

DOI: $10.17148 /$ IARJSET.2021.81212

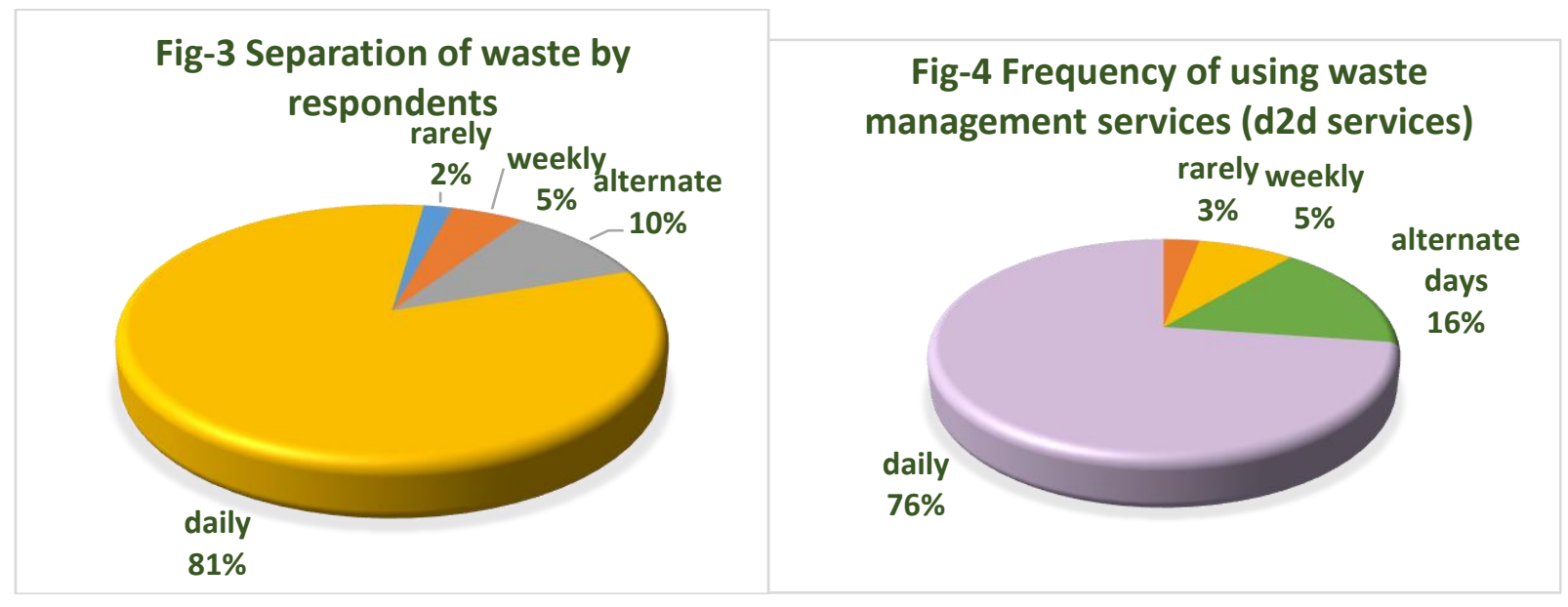

Fig 3 represents that more than four-fifth $(81 \%)$ of the respondents separate biodegradable and non-biodegradable waste daily at their household. While one-tenth $(10 \%)$ of the respondents separate biodegradable and non-biodegradable waste at alternate days at their household.

Fig 4 represents that one-fourth of the respondents (76\%) used waste management services provided by the university at daily basis and only $3 \%$ or the respondents used waste management services rarely.

\subsection{Environmental Benefits Observed by Respondents:}

This section elicited the environmental benefits observed by respondents as a result of household waste management through vermicompost production. 
DOI: 10.17148/IARJSET.2021.81212

\title{
Figure 5. Environmental Benefits Observed by Respondents as a Result of Household Waste Management through vermicomposting technology
}

\author{
$\square$ Strongly agree $\square$ Agree $\square$ Neutral $\square$ Disagree $\square$ Strongly disagree
}

reduction in unhealthy surrounding made by stray animals

Improvement in soil quality in nearby area of public dustbin

Reduction in Proliferation of insects and pests

Reduction in stench from overfilled garbage bins

Reduction of problems of overflowing and waterlogging

Eco-friendly products and results

Safer world lower potential harm humans

Greener and healthier environment than before.

Elimination waste and minimize of toxic gases

Comparatively looks cleaner before

Reduction of burning of waste

Reduction of waste disposal in random areas .
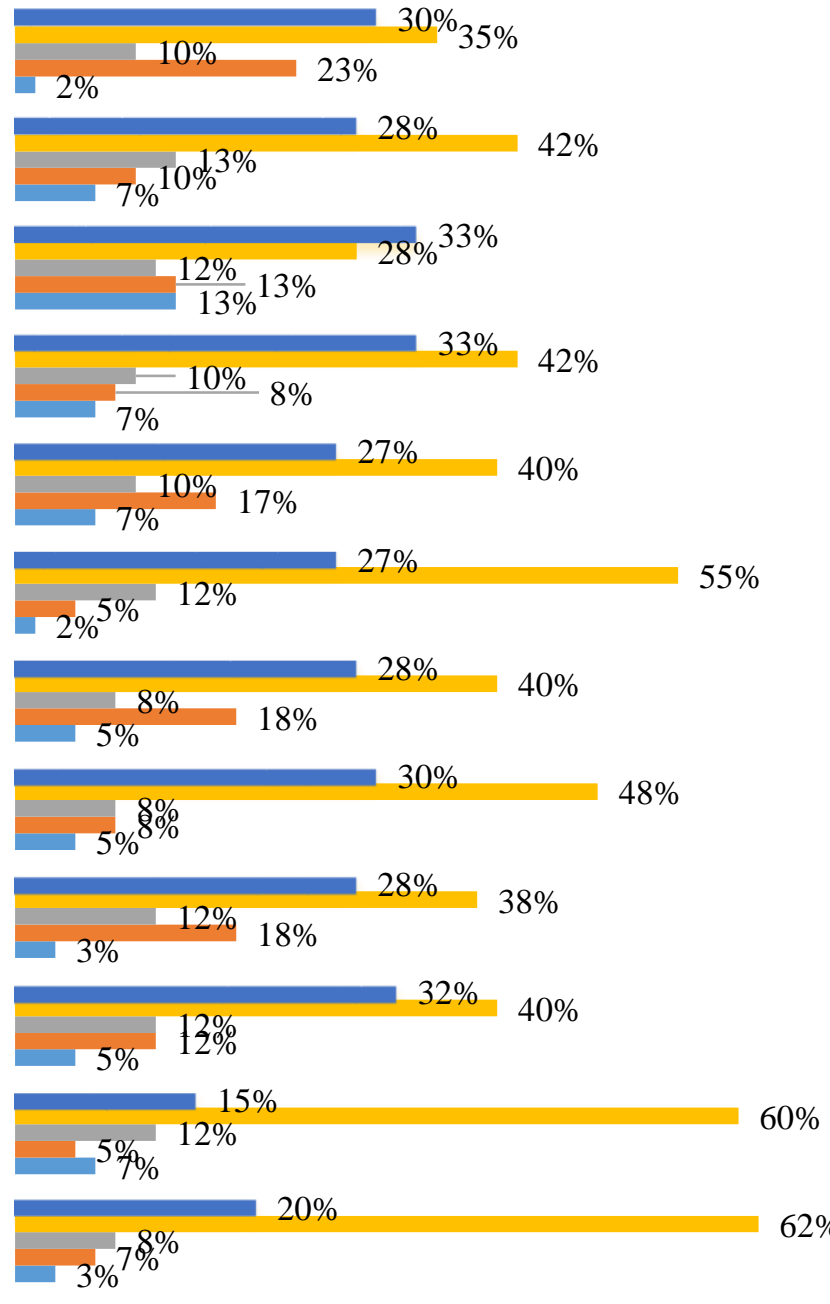

Lucid examination of the fig 5 exemplifies that respondents were agreed that there were reduction of waste disposal in random areas $(62 \%)$, reduction of burning of waste $(60 \%)$ and ecofriendly products and results came out from the waste management through vermicomposting. Respondents were strongly agreed that there were reduction in proliferation of insects and pests (33\%), reduction in stench from overfilled garbage bins (33\%) and reduction of problems of overflowing and waterlogging (27\%).

Respondents were disagreed from the statements like elimination waste and minimization of toxic gases (18\%), reduction of problems of overflowing and waterlogging (17\%) and reduction in proliferation of insects and pests $(13 \%)$.

3.5 Revenue Generation Through the HSW Through Vermicomposting Technology: This section deals with the possible revenue generated through the household waste management through vermicomposting technology which includes the total expenses: fixed cost, variable cost, net income, net benefits and cost benefit ratio. 
International Advanced Research Journal in Science, Engineering and Technology

Vol. 8, Issue 12, December 2021

DOI: 10.17148/IARJSET.2021.81212

Table 2 Evaluation of Possible Revenue Generation Through the HSW Through Vermicomposting Technology

\begin{tabular}{|c|c|c|c|}
\hline \multicolumn{2}{|c|}{ Terms } & \multirow{2}{*}{$\begin{array}{l}\text { Category } \\
\text { Rikshaw (thela/ waste cart) } \\
\text { Machine ( sieve) } \\
\text { Shredder machine } \\
\text { Cost of dustbins } \\
\text { Wages/ salary } \\
\text { Earthworms( red wigglers) }\end{array}$} & \multirow[t]{2}{*}{ Amount in INR } \\
\hline 1. & Fixed cost & & \\
\hline 2. & Variable cost & $\begin{array}{l}\text { Cow dung } \\
\text { Electricity bill } \\
\text { Other day to day expenses }\end{array}$ & INR $4,45,804.7$ \\
\hline A. & Total expenses/ cost & - & INR 10,42,135 \\
\hline \multirow{4}{*}{\multicolumn{2}{|c|}{ Income }} & Sale of Vermicompost (865.9Q) & INR4,07,795.3 \\
\hline & & Sale of Earthworms (750.0Q) & INR3,53,225.8 \\
\hline & & Work in progress & INR1,56,400.5 \\
\hline & & Earthworm available for sale & INR5,88,709.7 \\
\hline B. & Net Income & - & INR 15,06,131 \\
\hline C. & Net Benefits & B-A & INR 463996.6 \\
\hline & Cost benefit ratio & $1+\frac{\text { Net Benefit }}{\text { Total expenses }}$ & 1.44 \\
\hline
\end{tabular}

The table 2 illustrates that the total expenses/cost were INR 10,42,135 per annum. The net income were INR $15,06,131$ per annum. The net income were INR15,06,131 per annum and net benefit were INR 463996.6. The data revealed final results of cost benefit ratio was 1.44 . This demonstrated that vermicomposting as a technique for household waste management is a practical and accessible enterprise that may produce income and employment.

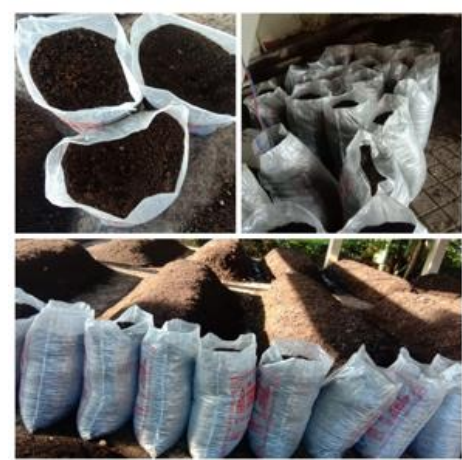

Prepared vermicompost @ 75/kg
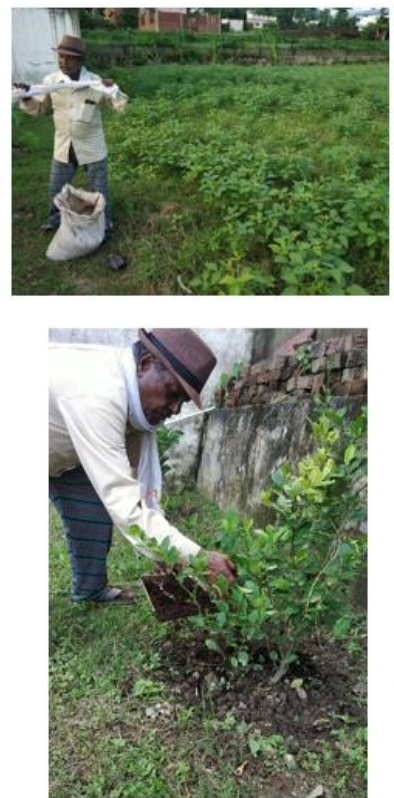

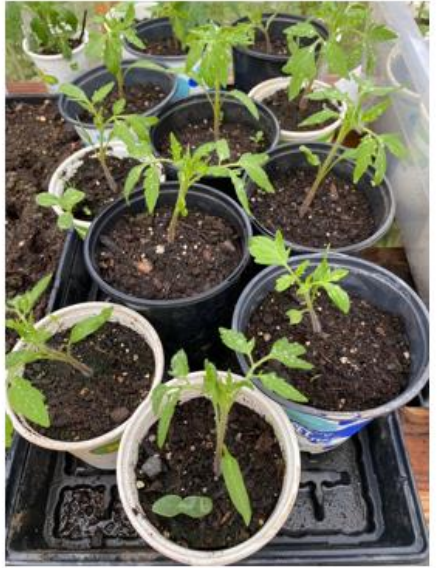

Use of Vermicompost in farm and garden

Fig 6. Prepared Vermicompost from the Household's Waste and its Utilization in Farm, Garden and Pots 


\author{
Vol. 8, Issue 12, December 2021 \\ DOI: $10.17148 /$ IARJSET.2021.81212 \\ 4. CONCLUSION AND IMPLICATION
}

The results of the study revealed that more or less every household in the university's residential area generates approximately $1.12 \mathrm{~kg}$ of waste, of which $68.75 \%$ was biodegradable and $31.25 \%$ was non-biodegradable waste. Respondents agreed that vermicomposting eliminates the use of chemical fertilizers in their gardens and farms (62\%), disposing of waste in random areas has been reduced (55\%), it helps to create a greener and healthier environment than before (48\%) and stench from overfilled garbage bins and uncollected waste on roadside has been reduced (42\%). The present study revealed the cost benefit ratio was 1.44 showed that vermicomposting as a tool of HWM could be an attainable and feasible enterprise and hence can generate the revenue and employment. As a result vermicomposting is the preferable alternative for managing domestic organic waste, as one seed feeds two birds. Household waste management, which included the generation of vermicompost, helped to alleviate the problem of organic waste (gila Kachra) in the area while also conserving the environment.

Farmers and youth can use vermicomposting technology to create cash and reduce unemployment by starting businesses and building large-scale vermicomposting companies. Many institutes, such as Dr. RPCAU Pusa Samastipur, IIT Roorkee, NIT Calicut, MNIT Jaipur, and RD National College in Bandra, are undertaking a "zero waste" project on their campus by employing various methods such as recycling, composting, and vermicomposting to maintain their surroundings healthy. As a result, any institute or company can start such initiatives and promote environmentally friendly waste management methods. In order to have a good impact on the environment, this study encourages both government and commercial companies to employ eco-friendly technology to reduce, recycle, and manage trash through vermicomposting. In addition, the current study encourages youth and farmers to embrace low-cost HWM technologies like vermicomposting to reap major benefits and boost agricultural profitability.

\title{
REFERENCES:
}

1. Das, A.K., Prasad, B., Singh, R.S., \& Kumari, B., (2017). Vermicomposting: Success story of farmer for revenue \&employment generation. International Journal of Agriculture Sciences.9(41):4664-4666

2. Desa, A., Abu Kadir, NB. \& Yusooff, F. (2012). Environmental awareness \&education: A ey approach to solid waste management (SWM)- a case study of university in Malaysia. Infotechopen.com Open Access Books. 1-2

3. Gutberlet, J., \& Uddin, S.M.N. (2017). Household waste and health risks affecting waste pickers and the environment in low- and middle-income countries. International journal of occupational and environmental health, 23(4), 299-310. Retrieved on September 21 , 2021 from https://doi.org/10.1080/10773525.2018.1484996

4. Hanc, A. \& Pliva, P. (2013). Vermicomposting technology as a tool for nutrient recovery from kitchen bio-waste. Journal Mater Cycles Waste Management, 15:431-439.

5. Heynen N, Kaika M, Swyngedouw E, Eds. In the nature of cities: urban political ecology and the politics of urban metabolism. London: Routledge; 2006.

6. IORA Ecological Solution (2014). India Organic Waste Management Programme (IOWMP). Satyoma Initiative Organisation. Retrieved on September 21, 2021 from https://satoyama-initiative.org/case_studies/india-organic-waste-management-programme-iowmp/

7. King A, Burgess S, Ijomah W, et al. (2006). Reducing waste: repair, recondition, remanufacture or recycle? Sustainable Dev. 2006;14(4):257-267.

8. Maan, D. (2014). 'Agri Clinics \& Agribusiness Centers (MANAGE)' Retrieved on september 8, 2021 from https://www.manage.gov.in/stry\&fcac/content/20.\%20Project\%20Report\%20on\%20Vermicompost.pdf

9. Sharma, K. \& Garg V.K.( 2019). Vermicomposting of waste: a zero-waste approach for waste management. Sustainable Resource Recovery \&Zero Waste Approaches (Elsevier) 2019:133-164

10. State of Green (2020). Retrieved on September 21, 2021 from https://stateofgreen.com/en/sectors/waste/

11. The World bank, Retrieved on September 21, 2021 from https://www.worldbank.org/en/news/immersive-story/2018/09/20/what-a-waste-anupdated-look-into-the-future-of-solid-waste-management?cid=EXT_WBTweetableSocialShare_EXT via @WorldBank 